\title{
Tissue Hydrogen Ion Concentration in Ischemic Muscle: Effects of Gradual and Acute Arterial Occlusion, with and without Acute Venous Hypertension ${ }^{1}$
}

\author{
Bruce L. Gewertz, M.D., ${ }^{2}$ James C. Stanley, M.D., and William J. Fry, M.D. \\ Department of Surgery, Section of General Surgery, University of Michigan Medical Center, Ann Arbor
}

Submitted for publication January 27, 1977

Accurate assessment of extremity ischemia is often a prerequisite to the successful completion of complex arterial reconstructions. Muscle surface $\mathrm{pH}$, reflecting the status of local tissue metabolism, offers a means for continuously monitoring limb perfusion. The present investigation was designed to evaluate muscle surface $\mathrm{pH}$ measurements in ischemic canine hindlimbs. These measurements, subjected to careful statistical analysis, were related to extremity blood flow, perfusion pressure, effluent blood $\mathrm{pH}$, and arteriovenous oxygen differences.

\section{MATERIALS AND METHODS}

Twenty-five adult mongrel dogs weighing 23.5 to $31.0 \mathrm{~kg}$ were anesthetized with intravenous pentobarbital $(30 \mathrm{mg} / \mathrm{kg}$ ) and mechanically ventilated. The infrarenal aorta and vena cava were exposed through a midline abdominal incision and encircled with adjustable vascular clamps. All animals were anticoagulated with intravenous sodium heparin ( 100 units $/ \mathrm{kg}$ ). Hydration was maintained by administration of lactated Ringer's solution $(100 \mathrm{ml} / \mathrm{hr})$. Polyethylene catheters for pressure measurements and blood samples were placed in the thoracic aorta as well as the iliac artery and vein. Catheters were connected to Statham pres-

\footnotetext{
${ }^{1}$ Supported by an award from the Conrad Jobst Foundation for Vascular Research.

${ }^{2}$ Correspondence to Dr. B. L. Gewertz, 3959 Clinical Faculty Office Building, University Hospital, 1405 E. Ann Street, Ann Arbor, Michigan 48109.
}

sure transducers and a Sanborn recorder. Carolina Instruments square wave electromagnetic flow probes, placed about the iliac artery, were connected to a flowmeter and recorder. An Orion glass $\mathrm{pH}$ probe was carefully inserted in the hindlimb, on the sartorius muscle surface, and attached to an expanded-scale $\mathrm{pH}$ meter. Probes were calibrated before and after use with appropriate adjustments made for body temperature. Baseline measurements were obtained following 30-min stabilization periods. All muscle surface $\mathrm{pH}$ values, $\mathrm{pH}_{\mathrm{m}}$, were converted to hydrogen ion concentration, $[\mathrm{H}+]_{\mathrm{m}}$. Conversion of muscle surface $\mathrm{pH}$ and blood $\mathrm{pH}$, representing exponential expressions of $[\mathrm{H}+]$, to hydrogen ions in nanomoles per liter was mandatory before valid statistical comparisons could be made. Results were analyzed by Student's $t$ test (between Groups I and II), paired $t$ test (within Groups I and II), or regression analysis (Group III).

\section{Group I}

Ten dogs underwent 60 -min complete infrarenal aortic occlusion. Ischemic limb venous blood and systemic arterial blood $p \mathrm{O}_{2}, p \mathrm{CO}_{2}$, and $\mathrm{pH}$ were measured under control conditions and at $30-\mathrm{min}$ intervals postocclusion. Blood flow, blood pressure, and $\mathrm{pH}_{\mathrm{m}}$ were documented at 10 -min intervals. Following aortic declamping, all variables were recorded for an additional 30 min. Blood gases were analyzed 2 min after unclamping. 


\section{Group II}

Five animals were subjected to distal inferior vena cava occlusion. Peripheral venous pressures subsequently increased to 20-23 $\mathrm{mm} \mathrm{Hg}$. Iliac artery flow, venous and arterial pressures, and $\mathrm{pH}_{\mathrm{m}}$ were recorded for $30 \mathrm{~min}$, at which time aortic occlusion for $60 \mathrm{~min}$ was effected. Upon aortic clamping, with maintenance of cava occlusion, the protocol outlined in Group I was followed.

\section{Group III}

Ten dogs were studied under control conditions with a mean arterial blood pressure of $112 \pm 16 \mathrm{~mm} \mathrm{Hg}$. Mean perfusion pressures were then lowered sequentially to (a) 100 , (b) 70 , and (c) 20 to $60 \mathrm{~mm} \mathrm{Hg}$ upon complete aortic occlusion. Arterial and venous blood $p \mathrm{O}_{2}, p \mathrm{CO}_{2}$, and $\mathrm{pH}$ were measured after 20 -min stabilization periods at each pressure. Iliac artery blood flows and $\mathrm{pH}_{\mathrm{m}}$ were compared to venous blood gas and $\mathrm{pH}$ changes at differing perfusion pressures.

\section{RESULTS}

\section{Group I: Aortic Occlusion (Table 1)}

The mean control $\left[\mathrm{H}^{+}\right]_{\mathrm{m}}$ was $58.9 \pm 24.9$ nmol/liter, corresponding to a $\mathrm{pH}_{\mathrm{m}}$ of 7.23. Sixty-minute aortic occlusion increased $\left[\mathrm{H}^{+}\right]_{\mathrm{m}}$ to $91.5 \pm 45.6 \mathrm{nmol} / \mathrm{liter}$, representing a $\mathrm{pH}_{m}$ of 7.04 . These values were significantly different, $p<0.01$. Iliac artery flow decreased from $194 \pm 79$ to 28 $\pm 19 \mathrm{ml} / \mathrm{min}$ with occlusion of the aorta. Ten minutes following declamping, $\left[\mathrm{H}^{+}\right]_{\mathrm{m}}$ decreased (65.2 $\pm 30.0 \mathrm{nmol} /$ liter, $\left.\mathrm{pH}_{\mathrm{m}} 7.19\right)$ toward preexistant levels. All data is presented as mean $\pm 1 \mathrm{SD}$.

Control limb venous $p \mathrm{O}_{2}$ was $43.0 \pm 8.3$ $\mathrm{mm} \mathrm{Hg}$. The venous $p \mathrm{O}_{2}$ fell significantly to $26.2 \pm 4.9$ and $28.9 \pm 4.5 \mathrm{~mm} \mathrm{Hg}$ during early and late aortic occlusion, $p<0.001$ and $p<0.01$, respectively. After declamping, venous $p \mathrm{O}_{2}$ increased to $42.1 \pm 4.7 \mathrm{~mm}$ $\mathrm{Hg}$. The limb venous $p \mathrm{CO}_{2}$ of $31.8 \pm 10.0$ $\mathrm{mm} \mathrm{Hg}$ in controls rose to $34.8 \pm 10.4$ and
$33.2 \pm 10.5$ during occlusion. These changes, although minimal, proved statistically different, $p<0.01$. Upon unclamping the aorta venous $p \mathrm{CO}_{z}$ showed little alteration, $33.0 \pm 9.2 \mathrm{~mm} \mathrm{Hg}$. The ischemic limb venous blood $\mathrm{pH}$, converted to $\left[\mathrm{H}^{+}\right]$, reflected increasing acidosis with arterial occlusion. The control values of $32.1 \pm 8.2$ $\mathrm{nmol} /$ liter rose slightly but significantly to $34.3 \pm 7.4$ and $33.9 \pm 7.5 \mathrm{nmol} /$ liter during the early and late occlusion period, $p$ $<0.05$ and $p<0.02$, respectively. Following aortic declamping, the venous $\left[\mathrm{H}^{+}\right]$ increased to $35.3 \pm 7.8 \mathrm{nmol} / \mathrm{liter}$, a higher level than control values, $p<0.01$.

\section{Group II: Cava and Aortic Occlusion (Table 2)}

The mean control $\left[\mathrm{H}^{+}\right]_{\mathrm{m}}$ was $56.6 \pm 10.0$ $\mathrm{nmol} /$ liter, corresponding to a $\mathrm{pH}_{\mathrm{m}}$ 7.25. Vena cava occlusion for $30 \mathrm{~min}$ did not significantly alter $\left[\mathrm{H}^{+}\right]_{\mathrm{m}}(61.0 \pm 10.0 \mathrm{nmol}$ liter, $\mathrm{pH}_{\mathrm{m}} 7.21$ ). Vena cava clamping did decrease iliac artery blood flow markedly from $232 \pm 110$ to $60 \pm 23 \mathrm{ml} / \mathrm{min}, \quad p<0.02$. Sixty-minute aortic occlusion, with concomitant cava occlusion, increased $\left[\mathrm{H}^{+}\right]_{\mathrm{m}}$ $\left(81.4 \pm 13.3 \mathrm{nmol} / \mathrm{liter}, \mathrm{pH}_{\mathrm{m}} 7.09\right)$. This proved significantly different than the control $\left[\mathrm{H}^{+}\right]_{\mathrm{m}}, p<0.001$. Aortic occlusion decreased flow further to $30 \pm 11 \mathrm{ml} / \mathrm{min}$. Upon aortic declamping, $\left[\mathrm{H}^{+}\right]_{\mathrm{m}}$ returned toward normal $\left(58.0 \pm 12.3 \mathrm{nmol} /\right.$ liter, $\mathrm{pH}_{\mathrm{m}}$ 7.24).

Ischemic limb venous $p \mathrm{O}_{2}$ decreased to $26.0 \pm 7.0 \mathrm{~mm} \mathrm{Hg} 30 \mathrm{~min}$ following cava occlusion. During early and late aortic occlusion, venous $p \mathrm{O}_{2}$ fell further to $19.6 \pm 6.7$ and $20.6 \pm 6.3 \mathrm{~mm} \mathrm{Hg}$. These values were significantly different from those preceding aortic occlusion, $p<0.01$ and $p<0.05$, respectively. Release of the aortic clamp resulted in venous $p \mathrm{O}_{2}$ rising to $30.2 \pm 8.1 \mathrm{~mm}$ $\mathrm{Hg}$. Ischemic limb venous $p \mathrm{CO}_{2}$, after cava occlusion and before aortic clamping of 33.0 $\pm 5.1 \mathrm{~mm} \mathrm{Hg}$, rose to $40.0 \pm 6.8$ and 40.4 $\pm 5.3 \mathrm{~mm} \mathrm{Hg}$ during early and late aortic occlusion. These changes were significantly 
TABLE 1

Group I-Aortic Occlusion: Muscle Surface Hydrogen Ion Concentrations (IN NANOMOLES PER LITER)

\begin{tabular}{cccc}
\hline Animal & Control & $\begin{array}{c}\text { During } \\
\text { aortic occlusion }\end{array}$ & $\begin{array}{c}\text { After } \\
\text { aortic declamping }\end{array}$ \\
\hline 1 & 39.8 & 57.7 & 38.0 \\
2 & 93.3 & 182.0 & 95.5 \\
3 & 44.7 & 61.7 & 35.5 \\
4 & 41.7 & 56.2 & 44.7 \\
5 & 24.6 & 50.1 & 36.3 \\
6 & 67.6 & 114.8 & 100.0 \\
7 & 39.8 & 57.5 & 43.7 \\
8 & 58.9 & 81.3 & 61.7 \\
9 & 83.2 & 102.3 & 87.1 \\
10 & 95.5 & 151.4 & 109.6 \\
Mean \pm 1 SD & $58.9 \pm 24.9$ & $91.5 \pm 45.6^{*}$ & $65.2 \pm 30.0^{* *}$ \\
\hline
\end{tabular}

* Statistically significant $\left[\mathrm{H}^{+}\right]_{\mathrm{m}}$ increase in comparison to control $(p<0.01)$.

** No difference in comparison to control.

different, $p<0.02, p<0.01$, respectively. After aortic declamping, $p \mathrm{CO}_{2}$ remained elevated in comparison to controls, 41.8 $\pm 7.0 \mathrm{~mm} \mathrm{Hg}, p<0.02$. The ischemic limb venous blood $\left[\mathrm{H}^{+}\right]$of $31.8 \pm 2.0 \mathrm{nmol} / \mathrm{liter}$ increased significantly to $35.4 \pm 3.1$ and 36.2 $\pm 2.6 \mathrm{nmol} /$ liter during early and late aortic occlusion, $p<0.05$ and $p<0.02$, respectively. Upon aortic declamping, venous blood $\left[\mathrm{H}^{+}\right]$increased to levels significantly greater than preocclusion values $(39.8 \pm 3.6$ nmol/liter, $p<0.02$ ).

\section{Comparison of Group I and II Data}

$\left[\mathrm{H}^{+}\right]_{\mathrm{m}}$ before, during, and after aortic occlusion were similar in both groups. Rates of the $\left[\mathrm{H}^{+}\right]_{m}$ return toward normal following aortic declamping were also comparable. Vena cava occlusion decreased femoral artery flow markedly but did not affect $\left[\mathrm{H}^{+}\right]_{\mathrm{m}}$. Nevertheless, ischemic limb venous blood $\mathrm{pO}_{2}$ in Group II was significantly lower than Group I at every interval studied (Table 3). Although Group II venous effluent $p \mathrm{CO}_{2}$ rose slightly

TABLE 2

Group II-Cava and Aortic Occlusion: Muscle Surface Hydrogen Ion Concentrations (IN NANOMOLES PER LITER)

\begin{tabular}{cllcc}
\hline Animal & Control & Cava occlusion & $\begin{array}{c}\text { Aortic }+ \text { cava } \\
\text { occlusion }\end{array}$ & $\begin{array}{c}\text { After } \\
\text { aortic declamping }\end{array}$ \\
\hline 1 & 43.7 & 45.7 & 61.6 & 38.0 \\
2 & 52.5 & 69.9 & 83.2 & 64.6 \\
3 & 70.8 & 70.8 & 97.7 & 69.2 \\
4 & 60.3 & 60.3 & 87.1 & 55.0 \\
5 & 55.0 & 58.9 & 77.6 & 63.1 \\
Mean \pm 1 SD & $56.5 \pm 10.0$ & $61.0 \pm 10.0^{*}$ & $81.4 \pm 13.3^{* *}$ & $58.0 \pm 12.3^{*}$ \\
\hline
\end{tabular}

* No difference in comparison to control.

** Statistically significant $\left[\mathrm{H}^{+}\right]_{\mathrm{m}}$ increase in comparison to control $(p<0.001)$. 
TABLE 3

Ischemic Limb Venous $p \mathrm{O}_{2}$ (In Millimeters of Mercury) with Aortic OCClusion

\begin{tabular}{lcc}
\hline & Group I & $\begin{array}{c}\text { Group II } \\
\text { (following cava occlusion) }\end{array}$ \\
\hline Before aortic occlusion & $43.0 \pm 8.3^{*}$ & $26.0 \pm 7.0^{*}$ \\
30 Minutes after aortic occlusion & $26.2 \pm 4.9$ & $19.6 \pm 6.7^{* *}$ \\
60 Minutes after aortic occlusion & $28.9 \pm 4.5$ & $20.6 \pm 6.3^{* *}$ \\
After aortic declamping & $42.1 \pm 4.7$ & $30.2 \pm 8.1^{*}$ \\
\hline
\end{tabular}

${ }^{a}$ Group II statistically lower than Group I at each interval; all data expressed as mean $\pm 1 \mathrm{SD}$

${ }^{*} p<0.01$.

${ }^{* *} p<0.05$.

after aortic declamping, a comparison of ischemic limb venous $p \mathrm{CO}_{2}$ and $\left[\mathrm{H}^{+}\right]$between Groups I and II revealed no significant differences. Systemic arterial blood gases did not change during the study in either Group I or II.

\section{Group III: Gradual Aortic Occlusion}

Results of progressive limb ischemia were tested by regression analysis. Iliac artery blood flow decreased linearly with diminutions in limb perfusion pressure $(1.41 \pm .52$ $\mathrm{ml} / \mathrm{min} / \mathrm{mm} \mathrm{Hg}$, slope significantly greater than $0, p<0.05) .\left[\mathrm{H}^{+}\right]_{\mathrm{m}}$ rose progressively with decreasing perfusion pressure

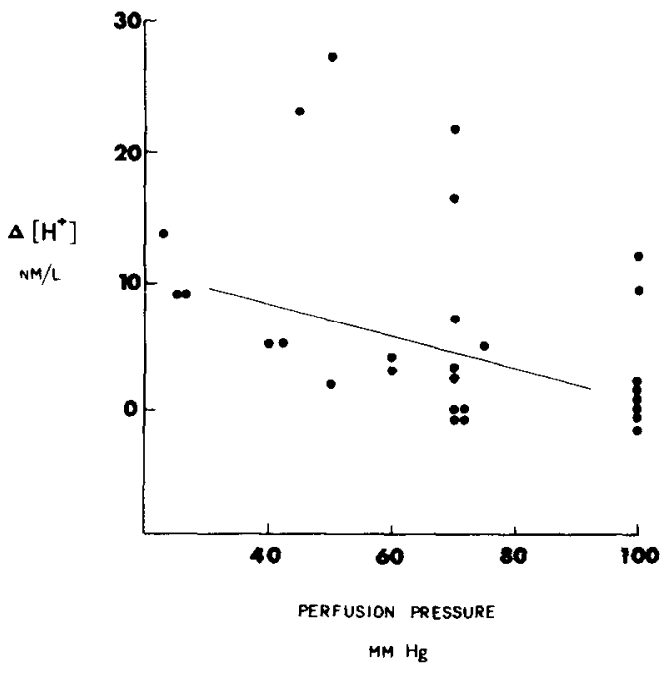

FIG. 1. Progressive $\left[\mathrm{H}^{+}\right]_{m}$ increases with decreased perfusion pressure. Average slope of all studies was $-0.12 \pm 0.09 \mathrm{nmol} / \mathrm{liter} / \mathrm{mm} \mathrm{Hg}$ (slope significantly less than $0, p<0.05$ ).
(Fig. 1) at a rate of $-0.12 \pm 0.09 \mathrm{nmol} /$ liter/mm $\mathrm{Hg}$ (slope significantly less than $0, p<0.05$ ). Arteriovenous oxygen differences increased with diminutions in pressure (Fig. 2) at a rate of $-.07 \pm .02 \mathrm{ml}$ of $\mathrm{O}_{2} / 100 \mathrm{~cm}^{3} / \mathrm{mm} \mathrm{Hg}$ (slope significantly less than $0, p<0.05$ ). Limb oxygen consumption ( $\mathrm{ml}$ of $\mathrm{O}_{2} / \mathrm{min}$ ) was measured in six dogs. Significant decreases in oxygen consumption, coincident with lowered perfusion pressures, were observed in only two animals.

\section{DISCUSSION}

Successful surgical management of peripheral arterial occlusive disease requires careful evaluation of clinical symptomatology, detailed arteriographic studies, and physiologic measurements documenting functional impairment. Quantitation of tissue ischemia remains an elusive task at the bedside as well as in the laboratory. As arterial reconstructive techniques advance and complex operations become more common, measurements of tissue perfusion assume greater importance. Muscle surface pH measurements utilizing percutaneously placed microelectrodes offer a relatively simple and safe means of quantitating the effectiveness of tissue perfusion.

Acute $\left[\mathrm{H}^{+}\right]$increases are known to occur on various organ surfaces with onset of anaerobic metabolism [3]. Anerobic shifts may be a consequence of direct tissue trauma, hemorrhage, inadequate oxygenation, or arterial occlusion $[1,7,14]$. 


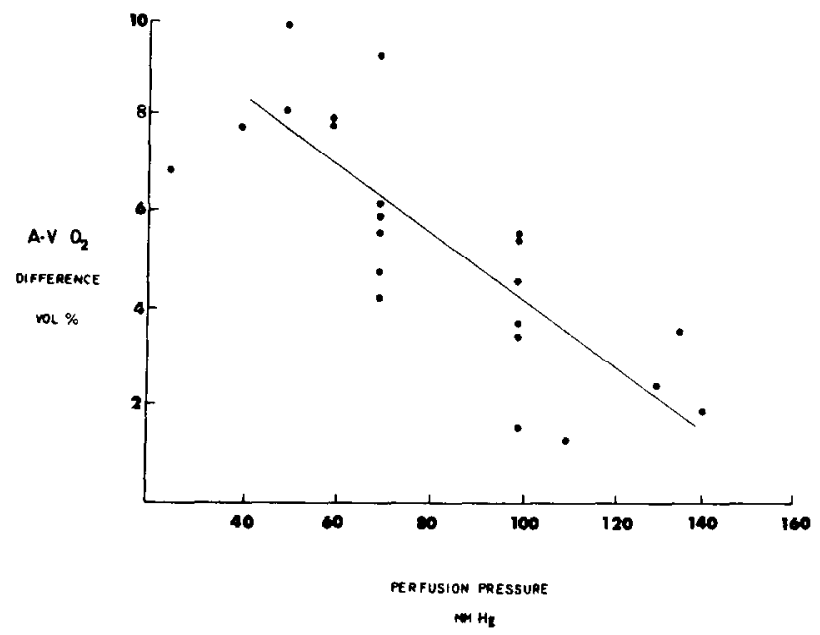

FIG. 2. Arteriovenous oxygen difference increases with diminutions in perfusion pressure. Average slope of all studies was $-0.07 \pm 0.02 \mathrm{ml}$ of $\mathrm{O}_{2} / 100 \mathrm{~cm}^{3} / \mathrm{mm} \mathrm{Hg}$ (slope significantly less than $0, p<0.05$ ).

Skeletal muscle metabolism is particularly liable to rapid change with ischemia from oxidative phosphorylation to anaerobic glycolysis. Intricate measurements of muscle gas tensions utilizing mass spectrometry have substantiated the anticipated biochemical changes reflected by $\left[\mathrm{H}^{+}\right]_{\mathrm{m}}$ fluctuations [5].

Earlier laboratory experiences support practical applications of $\mathrm{pH}_{\mathrm{m}}$ monitoring. Limited clinical use in pediatric and adult patients has provided rather accurate monitoring of systemic acid-base disturbances [4]. One group investigating eight patients undergoing reconstructive arterial surgery reported a low $\mathrm{pH}_{\mathrm{m}}$ in ischemic limbs that returned towards normal following successful revascularizations [2]. A recent report has documented lower $\mathrm{pH}_{\mathrm{m}}$ measurements in patients experiencing ischemic rest pain compared to those having claudication [12].

In the present investigation all animals exhibited increased hindlimb $\left[\mathrm{H}^{+}\right]_{\mathrm{m}}$ with isolated aortic occlusion (Group I). Systemic acid-base balance was not appreciably altered. Acidosis and lower oxygen tensions of ischemic limb venous effluent during aortic occlusion are in agreement with previous clinical and laboratory findings [6]. Tissue acidosis abated within 5 to $10 \mathrm{~min}$ following normalization of blood flow in the present study. Although aerobic metabolism resumes with normal circulation, it is unlikely that this is responsible for the quick return of $\left[\mathrm{H}^{+}\right]_{m}$ to normal. Rapid equilibrations suggest that the restored circulation effectively "washed out" local increases in hydrogen ion $[10,11]$. Actual clearance of acidic metabolites has been documented histochemically in serial biopsies of ischemic and postischemic skeletal muscie [8].

Isolated vena cava occlusion (Group II) produced sustained peripheral venous hypertension. Concomitant diminutions in arterial blood flow with this maneuver were anticipated [15]. Importantly, $\mathrm{pH}_{\mathrm{m}}$ in the present study was not altered by the marked decrease in iliac artery flow accompanying cava occlusion. Analysis of ischemic limb venous $p \mathrm{O}_{2}$, being significantly lower after cava occlusion, provided a possible explanation for this phenomenon. Increased oxygen extraction, facilitated by the venous hypertension of cava occlusion, perhaps favors normal metabolic pathways. This effect may persist in the face of moderate decreases in arterial flow. On the other hand, complete aortic occlusion, even with venous hypertension, caused rapid hindlimb $\left[\mathrm{H}^{+}\right]_{\mathrm{m}}$ increases. Although venous $p \mathrm{O}_{2}$ continued to fall in such a setting, compensatory extraction of sufficient oxygen to sustain normal metabolism may have been impossible. 
Iliac artery flow declined predictably with gradual reductions in perfusion pressure (Group III). Statistical tests of discrimination revealed consistent increases in $\left[\mathrm{H}^{+}\right]_{m}$ with decreases in iliac artery flow and pressure. Progressive increases in arteriovenous oxygen differences implicated increased local ischemic tissue oxygen extraction, inasmuch as systemic arterial $\rho \mathrm{O}_{2}$ remained stable. Increased arteriovenous oxygen differences in ischemic limbs of human subjects has been correlated with similar decreases in $\mathrm{pH}_{\mathrm{m}}$ [9]. In the current study significant increases in mean $\left[\mathrm{H}^{+}\right]_{\mathrm{m}}$ followed decreases in perfusion pressure. Occasional animals showed minute or no $\left[\mathrm{H}^{+}\right]_{\mathrm{m}}$ differences following small flow reductions at 100 $\mathrm{mm} \mathrm{Hg}$ perfusion pressures. Slight changes in flow may therefore be undetectable.

Alterations in $\left[\mathrm{H}^{+}\right]_{\mathrm{m}}$ must be interpreted in relation to the total body acid-base balance. Changes in systemic blood $\mathrm{pH}$ on a respiratory or metabolic basis predictably alters tissue $\left[\mathrm{H}^{+}\right][13]$. Similarly, acute hemorrhage or other sympathetic nervous system stimuli affect tissue $\mathrm{pH} .\left[\mathrm{H}^{+}\right]_{\mathrm{m}}$ correlates well with limb perfusion when ventilation and blood volume are controlled variables.

This investigation lends credence to the tenet that $\mathrm{pH}_{\mathrm{m}}$ monitoring provides a precise indicator of ischemic tissue metabolism. Incremental decreases in flow were easily detectable, especially if associated with hypotension. Discrimination was less sensitive at higher perfusion rates. An unanticipated finding of this study was that the metabolic sequelae of hypoperfusion associated with venous occlusion were seemingly compensated for by an apparent increase in tissue oxygen extraction. This experiment supports clinical usage of muscle surface $\mathrm{pH}$ monitoring as an objective means of assessing arterial insufficiency and quantitating the results of arterial reconstructive efforts.

\section{ACKNOWLEDGMENTS}

The authors acknowledge contributions to this work by James W. Crudup (Department of Surgery) and
George W. Williams (Department of Biostatistics) of the University of Michigan.

\section{REFERENCES}

1. Berman, I. R., Lemieux, M. D., and Aaby, G. V Responses of skeletal muscle $\mathrm{pH}$ to injury: A new technique for determination of tissue viability. Surgery 67: 507, 1970.

2. Couch, N. P., Dmochowski, J. R., Van De Water, J. M. et al. Muscle surface $\mathrm{pH}$ as an index of peripheral perfusion in man. Ann. Surg. 173: 173. 1971.

3. Couch, N. P., and Middleton, M. K. Effect of storage temperature on the electrometric surface hydrogen ion activity of ischemic liver and heart. Surgery 64: 1099, 1968.

4. Filler, R. M., Das, J. B., and Espinosa, H. M. Clinical experience with continuous muscle $\mathrm{pH}$ monitoring as an index of tissue perfusion and oxygenation and acid-base status. Surgery 72: 23, 1972.

5. Filler, R. M., Das, J. B., Schwartz, A. A. et al. Continuous monitoring of muscle gas tensions and $\mathrm{pH}$ during tissue acid-base disturbances. $J$. Pediatr. Surg. 9: 633, 1974.

6. Fisher, R. D., Fogarty, T. J., and Morrow, A. G. Clinical and biochemical observations of the effect of transient femoral artery occlusion in man. Surgery 68: 323, 1970.

7. Gazzaniga, A. B., Byrd, C. L., and Gross, R. E. The use of skeletal muscle surface hydrogen ion concentration to monitor peripheral perfusion: Experimental and clinical results. Surg. Forum 21: $147,1970$.

8. Haljamae, H., and Enger, E. Human skeletal muscle energy metabolism during and after complete tourniquet ischemia. Ann. Surg. 182: 9, 1975.

9. Laks, H. L., Dmochowski, J. R., and Couch, N. $P$. The relationship between muscle surface $\mathrm{pH}$ and oxygen transport. Ann. Surg. 183: 193, 1976.

10. Lim, R. C., Jr., Bergentz, S. E., and Lewis, D. H. Metabolic and tissue blood flow changes resulting from aortic cross-clamping. Surgery 65: 304, 1969.

11. Mehl, R. L., Paul, H. A., Shorey, W. et al. Treatment of "toxemia" after extremity replantation. Arch. Surg. 89: 871, 1964.

12. O'Donnell, T. F., Jr. Measurement of percutaneous muscle surface $\mathrm{pH}$. Lancet II: 533, 1975.

13. Smith, R. N., Lemieux, M. D., and Couch, N. P. Effects of acidoses and alkaloses on surface skeletal muscle hydrogen ion activity. Surg. Gynecol. Obstet. 128: 533, 1969.

14. Van De Water, J. D., Philips, P. A., Linton, L. A. et al. Muscle surface $\mathrm{pH}$ monitoring. Arch. Surg. 104: 799, 1972.

15. Wright, C. B., and Swan, K. G.: Hemodynamics of venous occlusion in the canine hindlimb. Surgery 73: 141, 1973. 